\title{
Lipolysis and sensory characteristics of Cheddar cheeses ripened using different temperature-time treatments
}

\author{
James A. O’MAHONY, Elizabeth M. SHEEHAN, Conor M. DELAHUNTY**, \\ Paul L.H. McSWEENEY*
}

Department of Food and Nutritional Sciences, University College, Cork, Ireland

Received 29 November 2004 - Accepted 21 July 2005

\begin{abstract}
Commercial Cheddar cheeses were ripened under each of 7 temperature-time treatments ranging in temperature from 4 to $12{ }^{\circ} \mathrm{C}$ for a total of $270 \mathrm{~d}$. The levels of total and individual free fatty acids (FFA), as measured by gas chromatography, increased with increasing ripening temperature and progressive ripening time for all 7 cheeses. Increasing ripening temperature by $4{ }^{\circ} \mathrm{C}$, from 8 to $12{ }^{\circ} \mathrm{C}$, resulted in a greater relative increase in the accumulation of FFA than a ripening temperature increase of the same magnitude from 4 to $8{ }^{\circ} \mathrm{C}$. While increasing ripening temperature and time resulted in increases in the levels of short- $\left(\mathrm{C}_{4: 0^{-}} \mathrm{C}_{8: 0}\right)$, medium- $\left(\mathrm{C}_{10: 0^{-}} \mathrm{C}_{14: 0}\right)$ and long- $\left(\mathrm{C}_{16: 0^{-}}\right.$ $\mathrm{C}_{18: 3}$ ) chain FFA, the greatest relative increases in FFA levels were found for those in the shortchain FFA class. The results also suggested that the use of higher temperatures during the early stages of ripening ( 1 to $60 \mathrm{~d}$ ) was most effective at accelerating lipolysis. Descriptive analysis was used for assessment of the sensory properties of the cheeses during ripening. Cheddar cheese ripened at high temperature $\left(12^{\circ} \mathrm{C}\right)$ developed flavour and aroma profiles to an intensity characteristic of typical mature Cheddar cheese in a relatively short time $(120 \mathrm{~d})$. Conversely, irrespective of ripening time, Cheddar cheese ripened at low temperature $\left(4^{\circ} \mathrm{C}\right)$ did not attain the flavour and aroma characteristics typical of mature Cheddar cheese.
\end{abstract}

Cheddar cheese / ripening temperature / lipolysis / flavour / free fatty acids

\begin{abstract}
摘要 - 不同温度一时间下成熟的 Cheddar 干酪中脂肪水解和感官特性研究。将工厂生产出 的新鲜契达干酪 (Cheddar cheese) 分为 7 组, 分别在不同的温度和时间条件下成熟 $270 \mathrm{~d}$, 成 熟温度的变化范围在 $4 \sim 12^{\circ} \mathrm{C}$ 。采用气相色谱法测定了不同成熟时间和成熟温度下每组干 酪样品中每种游离脂肪酸含量以及游离脂肪酸总量, 试验结果表明在 7 组干酪中每种游离 脂肪酸和总游离脂肪酸的含量随着成熟温度的上升和成熟时间的延长而增加。同样是将成 熟温度升高 $4{ }^{\circ} \mathrm{C}$, 温度从 $8^{\circ} \mathrm{C}$ 升高到 $12^{\circ} \mathrm{C}$ 时干酪中游离脂肪酸含量要明显高于成熟温度由 $4{ }^{\circ} \mathrm{C}$ 升高到 $8{ }^{\circ} \mathrm{C}$ 时游离脂肪酸含量。随着成熟温度的上升和成熟时间的延长, 干酪中短链 $\left(\mathrm{C}_{4: 0} \mathrm{C}^{-} \mathrm{C}_{8: 0}\right)$ 、中链 $\left(\mathrm{C}_{10: 0^{-}} \mathrm{C}_{14: 0}\right)$ 和长链 $\left(\mathrm{C}_{16: 0^{-}} \mathrm{C}_{18: 3}\right)$ 游离脂肪酸含量也相应的增加, 尤其是短链 脂肪酸含量增加最为显著。同时还提出了在干酪成熟初期 (1-60天) 较高温度可以有效地促 进脂肪的水解。采用描述性分析方法评价了不同成熟期的干酪感官特性。成熟温度较高 $\left(12{ }^{\circ} \mathrm{C}\right)$ 的干酪在相对较短的成熟时间内就可以形成成熟契达干酪所具有的典型的浓郁芳香 味。反之, 如果不考虑成熟时间, 低温成熟 $\left(4^{\circ} \mathrm{C}\right)$ 的契达干酪不能获得成熟契达干酪所具有 的典型特征性风味。
\end{abstract}

契达干酪 / 成熟温度 / 脂肪水解 / 风味 / 游离脂肪酸

* Corresponding author (通讯作者): p.mcsweeney@ucc.ie

** Present address: Sensory Science Research Centre, University of Otago, PO Box 56, Dunedin, New Zealand 
Résumé - Lipolyse et caractéristiques sensorielles de fromage Cheddar affiné selon différents couples température-temps. L'affinage de fromage Cheddar industriel a été étudié en utilisant 7 traitements température-temps différents, allant de 4 à $12{ }^{\circ} \mathrm{C}$ et un maximum de 270 jours. Pour tous les fromages, plus la température d'affinage s'élevait, plus les niveaux d'acides gras libres (AGL), totaux et individuels, mesurés par chromatographie en phase gazeuse, augmentaient. Cette augmentation de l'accumulation des AGL était relativement plus grande lors du passage de 8 à $12^{\circ} \mathrm{C}$ que lors du passage de 4 à $8{ }^{\circ} \mathrm{C}$. L'élévation de la température et du temps d'affinage entraînait l'augmentation des niveaux d' $A G L$ à chaîne courte $\left(C_{4: 0^{-}} C_{8: 0}\right)$, moyenne $\left(C_{10: 0^{-}} C_{14: 0}\right)$ et longue $\left(C_{16: 0^{-}}\right.$ $\mathrm{C}_{18: 3}$ ), mais c'est la classe des AGL à chaîne courte qui présentait la plus grande augmentation relative. Les résultats ont aussi montré que l'utilisation des températures les plus élevées en début d'affinage (1 à 60 jours) était plus efficace sur l'accélération de la lipolyse. Une analyse descriptive a été utilisée pour évaluer les propriétés sensorielles des fromages au cours de l'affinage. Elle a montré que le fromage Cheddar affiné aux températures les plus élevées $\left(12^{\circ} \mathrm{C}\right)$ présentait, dans un temps relativement court (120 jours), des profils de flaveur et d'arôme d'intensité caractéristique d'un fromage Cheddar mature typique. Par contre, le fromage affiné à basse température $\left(4{ }^{\circ} \mathrm{C}\right)$ n'atteignait jamais ces caractéristiques quel que soit le temps d'affinage.

\section{fromage / Cheddar / température d'affinage / lipolyse / flaveur / acide gras libre}

\section{INTRODUCTION}

Cheese ripening involves a concerted series of microbiological, chemical and biochemical reactions that are ultimately responsible for the development of characteristic texture, flavour, aroma and appearance of individual cheese varieties [20]. Cheese flavour is extremely complex and is best explained by the "Component Balance Theory" [42], which proposes that cheese flavour is due to the interaction, in correct proportions, of many compounds, present at specific concentrations. The development of cheese flavour stems directly from biochemical activity during ripening. There are three primary routes by which biochemical activity proceeds in cheese during ripening; namely, proteolysis, lipolysis and the metabolism of residual lactose and of lactate and citrate [37]. The relative importance of each of these processes is largely dependant on cheese variety; however, proteolysis is believed to be the most complex, and to play a significant role in the ripening of nearly all varieties [20]. This is especially true in internal bacterially-ripened (e.g., Cheddar) and smear-ripened cheeses (e.g., Tilsit), in which it is considered the main biochemical event [57].

The extent of lipolysis in Cheddar cheese is normally low $[5,38]$, however, it is essential for good/balanced flavour. It has long been known that Cheddar cheese does not develop correct flavour when made from skim milk or milk in which the fat has been replaced with other lipids [15, 48, 59-61]. Lipolysis does not need to be very extensive to make a distinct contribution to the sensory properties of Cheddar cheese as free fatty acids can act as precursors for important flavour compounds (e.g., methyl ketones) [38] and short- and intermediatechain, even-numbered fatty acids $\left(\mathrm{C}_{4: 0^{-}}\right.$ $\mathrm{C}_{12: 0}$ ) have low flavour thresholds and each has a characteristic flavour note [3].

The physicochemical nature of the fat fraction and the enzyme complement of traditional Cheddar cheese are primarily responsible for the low extent of lipolysis during ripening. Ripening of Cheddar cheese is largely an enzymatic process [19] with the principal lipolytic enzymes in Cheddar cheese curd made from pasteurised milk reported to be lipases and esterases of lactic acid bacteria (LAB) [3, 25]. The activity of such enzymes is generally accepted as being weak or limited, especially towards triglyceride substrates $[2,20$, $24,54,56]$. The contribution of the indigenous milk lipoprotein lipase (LPL) to liberation of free fatty acids in maturing Cheddar cheese is limited, as it is largely inactivated by pasteurisation [6, 7]. However, a thermal treatment of $78{ }^{\circ} \mathrm{C}$ for $10 \mathrm{~s}$ is required for its complete inactivation [10]. It is possible that LPL acts synergistically with lipases and esterases of LAB in Cheddar cheese during ripening as it has been shown using a simple milk-based model system that LPL 
causes the conversion (albeit limited) of triglycerides to mono- and di-glycerides, for which lipases and esterases of $\mathrm{LAB}$ exhibit greater substrate specificity [30].

A multitude of approaches have been adopted to accelerate Cheddar cheese ripening [31, 58, 62]. A number of these approaches have shown, with varying success, acceleration of lipolysis in Cheddar cheese during ripening. The incorporation into Cheddar cheese curd of a number of exogenous lipases/esterases, either in pure form or as components of commercial enzyme preparations, such as pre-gastric esterase, Rhizomucor miehei lipase [32], Aspergillus oryzae lipase (component of the FlavorAge enzyme preparation) [1], Palatase 20000L and Lipase M [44] or Palatase M (as component of liposome-encapsulated enzyme cocktail) [29] have been demonstrated to increase the levels of free fatty acids during ripening. Modification of the natural fat globule size distribution of milk for Cheddar cheese manufacture by homogenisation [27], gravity separation [47] or using a fat-substituted cheese model [61] increases the extent of lipolysis during ripening. The use of LAB starter cultures that undergo autolysis early in ripening (e.g., Lactococcus lactis subsp. cremoris AM2) also results in increased accumulation of free fatty acids in Cheddar cheese [4].

Ripening temperature is the most important single factor responsible for the rate of development of flavour intensity in Cheddar cheese [33]. Increasing temperature as a means of accelerating ripening has the advantage of potential cost savings (maintenance of sub-ambient temperature storage) [12], is technologically simple [58] and there are no legal barriers. The major limitations of this technique are the increased risk of microbial spoilage and the development of unbalanced flavour [62]. In spite of its simplicity and effectiveness, elevated temperature has been the subject of relatively few studies to accelerate the ripening of Cheddar cheese $[11,16,22,23,45$, 49]. However, these researchers restricted their focus primarily to the study of proteolysis, in spite of the significant role played by lipolysis in the biogenesis of cheese flavour.
Descriptive sensory analysis has been used for the assessment of the sensory properties of Cheddar cheese for the past 1015 years [55]. It was not until relatively recently that a descriptive sensory language (lexicon) was developed specifically for the study of Cheddar cheese $[9,43]$. This development in sensory science has been shown to be a powerful technique for determining the sensory characteristics of Cheddar cheese ripened at elevated temperatures [23].

The objective of this study was to quantify total and individual free fatty acid levels in Cheddar cheeses ripened under different temperature-time treatments and to compare the rate and extent of lipolysis with the flavour and aroma sensory properties of the cheeses as determined by descriptive sensory analysis.

\section{MATERIALS AND METHODS}

\subsection{Cheese manufacture and ripening}

Cheddar cheeses were manufactured on a commercial scale using Lactococcus lactis subsp. lactis 303 (Chr. Hansen (Ireland) Limited, Rohan Industrial Estate, Little Island, Co. Cork, Ireland) as starter. Four consecutive cheese blocks $(20 \mathrm{~kg})$ were removed from the block-former, vacuum packaged and passed through a cooling tunnel, where the cheese was rapidly cooled to $4{ }^{\circ} \mathrm{C}$. Cheese blocks were held at $4{ }^{\circ} \mathrm{C}$ for $\sim 20 \mathrm{~h}$ after manufacture. In the laboratory, each of the blocks was sub-divided into 4 smaller blocks (5-6 kg) and vacuum packaged. Cheeses were ripened at three primary temperatures of 4,8 or $12^{\circ} \mathrm{C}$ for $270 \mathrm{~d}$. The ripening temperature of 4 cheeses was changed after $60 \mathrm{~d}$ from 4 to $8{ }^{\circ} \mathrm{C}, 8$ to $4{ }^{\circ} \mathrm{C}, 8$ to $12{ }^{\circ} \mathrm{C}$ or 12 to $8^{\circ} \mathrm{C}$. The temperature-time treatments used for ripening and the corresponding treatment codes are shown in Table I. All cheeses were ripened for $270 \mathrm{~d}$ and 2 cheeses were ripened under each of the 7 different temperature-time treatments. 
Table I. Temperature(s) and duration of ripening at each temperature used for each of the 7 ripening temperature-time treatments together with the respective treatment codes.

\begin{tabular}{lcc}
\hline $\begin{array}{l}\text { Treatment } \\
\text { code }\end{array}$ & Treatment temperature $\left({ }^{\circ} \mathrm{C}\right)$ \\
\hline & Before $60 \mathrm{~d}$ & After $60 \mathrm{~d}$ \\
$\mathrm{~A}$ & 4 & 4 \\
$\mathrm{~B}^{*}$ & 4 & 8 \\
$\mathrm{C}^{*}$ & 8 & 4 \\
$\mathrm{D}$ & 8 & 8 \\
$\mathrm{E}^{*}$ & 8 & 12 \\
$\mathrm{~F}^{*}$ & 12 & 8 \\
$\mathrm{G}$ & 12 & 12 \\
\hline
\end{tabular}

* Ripening temperature changed at $60 \mathrm{~d}$.

\subsection{Analysis of composition, lipolysis and enumeration of non-starter lactic acid bacteria}

Cheese samples were analysed in triplicate for $\mathrm{pH}$, moisture, fat, protein and salt, as described previously [46]. All compositional parameters were measured $1 \mathrm{~d}$ post manufacture, except for $\mathrm{pH}$, which was measured $30 \mathrm{~d}$ post manufacture. Nonstarter lactic acid bacteria (NSLAB) were enumerated on Rogosa agar [52] incubated anaerobically for $5 \mathrm{~d}$ at $30^{\circ} \mathrm{C}$. Enumeration of NSLAB was carried out in duplicate at all ripening times. Individual free fatty acids were extracted from cheeses ripened under each of the 7 temperature-time treatments at 60,120 and $270 \mathrm{~d}$ of ripening, using a solid-phase extraction technique, separated by gas chromatography, identified and quantified according to the method of De Jong and Badings [8], as described previously [47].

\subsection{Descriptive sensory analysis}

Samples (200 g) were cut from the cheeses at 120 and $270 \mathrm{~d}$ of ripening, vacuum packaged, frozen and maintained at $-20^{\circ} \mathrm{C}$ in the dark (wrapped in aluminium foil). For analysis, the samples were removed from frozen storage and allowed to thaw at $4{ }^{\circ} \mathrm{C}$ for $18 \mathrm{~h}$ prior to evaluation. A panel of 10 trained assessors (1 male,
9 female, aged between 35 and 50 years) was used to perform sensory analysis of the cheeses. All 10 assessors were members of an established sensory panel at University College, Cork, Ireland. The panel was recruited and screened according to international standards [26]. All assessors were first required to attend two group discussions, during which a list of descriptive attributes was formulated based on a vocabulary used previously by the panel [43] . Descriptive sensory analysis was performed using a vocabulary of 10 odour and 19 flavour terms. On the morning of assessment, the samples were removed from storage at $4{ }^{\circ} \mathrm{C}$, the outer layer $(5 \mathrm{~mm})$ of each cheese was removed and discarded and the remaining portion was cut into cubes $(\sim 5 \mathrm{~g})$. Each sample was equilibrated at room temperature $\left(20{ }^{\circ} \mathrm{C}\right)$ and presented as two 5-g cubes, in a clear-glass tumbler covered with a clock glass and coded with a randomly selected three-digit number. Each panellist was provided with de-ionised water and unsalted crackers to cleanse their palate between samples. A list of definitions for each of the attributes included in the final vocabulary was also available to each panellist. The sensory attributes of the cheeses were scored on unstructured $100 \mathrm{~mm}$ line scales labelled at both ends (at 5\% and 95\%) with extremes of each descriptive term. The intensity of each of the descriptive terms was recorded for each cheese and all cheeses were evaluated in duplicate. The data was collected using Compusense Five, Version 4.0 (Compusense Inc., Ontario, Canada). Descriptive sensory assessment of the cheeses was performed during 12 sessions with 6 cheeses evaluated in each of the first 11 sessions and 7 cheeses evaluated in the final session. The first cheese sample presented to the panellists at each session was the same, the results of which were disregarded. For the remaining 5/6 cheeses, the order of tasting was balanced to account for order of presentation and carry-over effects [34].

\subsection{Statistical data analysis}

One-way analysis of variance (ANOVA) of the composition data of the cheeses was conducted using SPSS Version 11.0 for Windows XP (SPSS Inc., Chicago, IL, USA). 


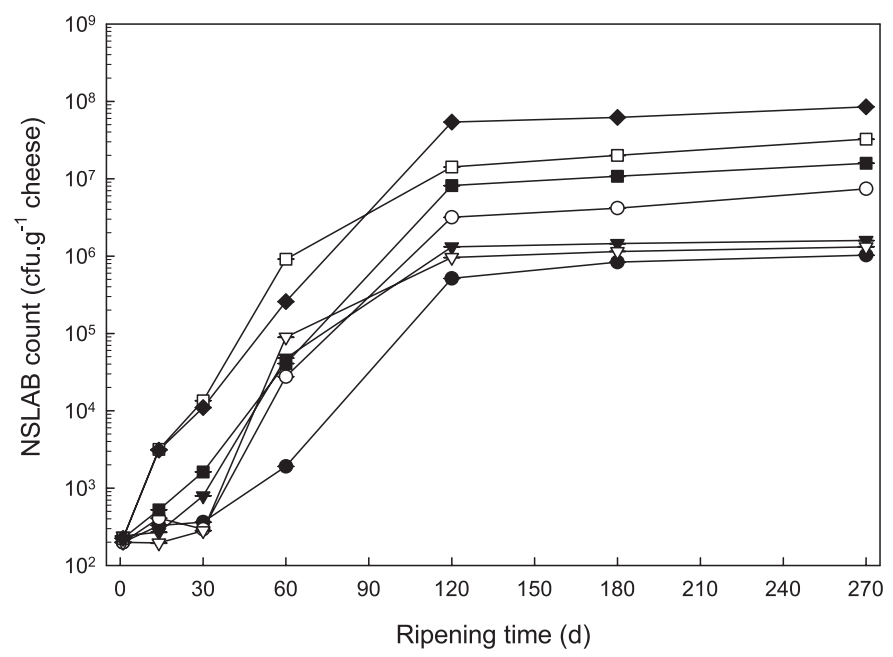

Figure 1. Numbers of non-starter lactic acid bacteria (NSLAB) in Cheddar cheeses ripened under conditions of each of treatments A $(\bullet-), \mathrm{B}(-0), \mathrm{C}(\boldsymbol{\nabla}), \mathrm{D}(-7), \mathrm{E}(-\mathbf{-}), \mathrm{F}(--)$ or $\mathrm{G}(-)$ for $270 \mathrm{~d}$. Averaged from duplicate analysis of cheeses from 2 trials. Error bars indicate \pm one standard deviation. See Table I for explanation of treatment codes.

Significance was declared at $P \leq 0.05$. The mean panel scores from descriptive sensory analysis were subjected to one way-ANOVA using SPSS to determine which attributes were effective at differentiating between the cheeses. The data was then subjected to principal component analysis using Guideline ${ }^{\circledR}$ v. 7.5 (CAMO AS, Oslo, Norway).

\section{RESULTS AND DISCUSSION}

\subsection{Composition and enumeration of non-starter lactic acid bacteria}

The moisture, fat, protein and salt contents of the 4 cheeses were $41.5 \pm 0.29,32.5 \pm$ $0.10,19.2 \pm 0.15$ and $2.41 \pm 0.06 \mathrm{~g} \cdot 100 \mathrm{~g}^{-1}$ respectively, while the $\mathrm{pH}$ was $5.38 \pm 0.05$. The values for moisture, $\mathrm{pH}$ and salt content of each of the four cheeses were slightly higher than would be expected for commercial Cheddar cheese [21]. However, there were no significant $(P>0.05)$ differences between the $\mathrm{pH}$, moisture, fat, protein or salt content of any of the 4 cheeses. It is clear from Figure 1 that the numbers of nonstarter lactic acid bacteria (NSLAB) were essentially identical in all cheeses at $1 \mathrm{~d}$ of ripening, with the numbers increasing during ripening for all cheeses to reach levels ranging from $10^{6}$ to $10^{8} \mathrm{cfu} \cdot \mathrm{g}^{-1}$ cheese at $270 \mathrm{~d}$. The numbers of NSLAB increased with increasing ripening temperature, with cheeses ripened under conditions of treatments $A$ and $G$ having NSLAB populations of $\sim 10^{6}$ and $10^{8} \mathrm{cfu} \cdot \mathrm{g}^{-1}$ cheese, respectively, at $270 \mathrm{~d}$. It is known that the principal lipolytic agents in Cheddar cheese made from pasteurised milk are lipases and esterases of lactic acid bacteria [3].

\subsection{Assessment of lipolysis}

The concentration of each of the 11 individual free fatty acids from butyric $\left(\mathrm{C}_{4: 0}\right)$ to linolenic $\left(\mathrm{C}_{18: 3}\right)$ acids, in each of cheeses $\mathrm{A}$ to $\mathrm{G}$ at 60,120 and $270 \mathrm{~d}$ of ripening are shown in Table II. In general, the level of each of the FFA increased with both ripening temperature $\left(4-12{ }^{\circ} \mathrm{C}\right)$ and ripening time (60-270 d). Irrespective of ripening temperature or time, the FFA present at the greatest concentration were palmitic $\left(\mathrm{C}_{16: 0}\right)$ and oleic $\left(\mathrm{C}_{18: 1}\right)$ acids. The concentrations 


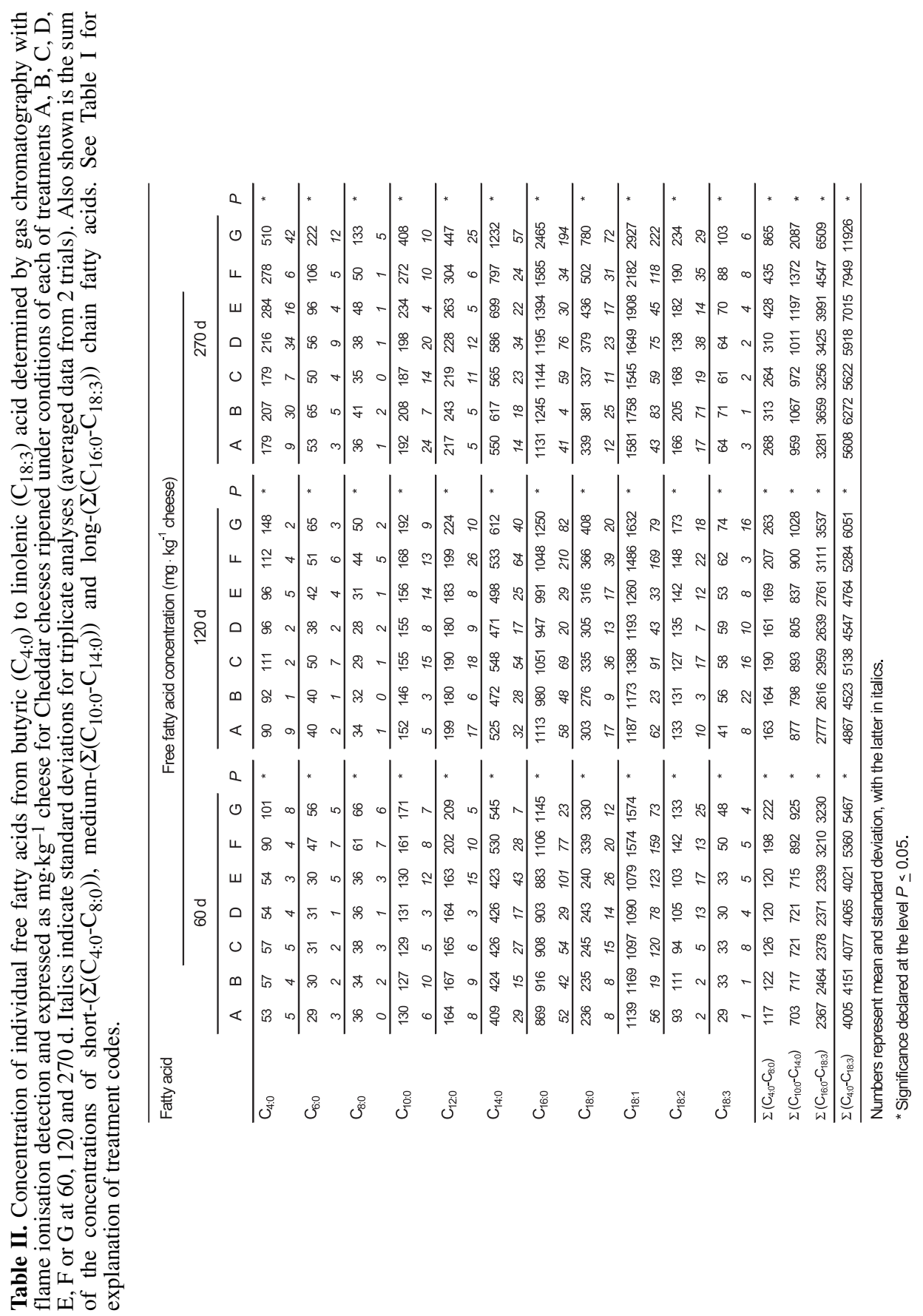


of palmitic and oleic acids ranged from 869 to 2465 and 1079 to $2927 \mathrm{mg} \cdot \mathrm{kg}^{-1}$ cheese, respectively. Identical trends have been reported previously for the relative concentrations of palmitic and oleic acids in maturing Cheddar cheese [4, 47]. At $60 \mathrm{~d}$ of ripening, there were no significant $(P>0.05)$ differences between the total FFA $\left(\Sigma\left(\mathrm{C}_{4: 0}-\mathrm{C}_{18: 3}\right)\right)$ content of any of the 5 cheeses A, B, C, D or E, with levels varying from 4005 to $4151 \mathrm{mg} \cdot \mathrm{kg}^{-1}$ for cheeses $\mathrm{A}$ and $\mathrm{B}$, respectively. However, the total FFA content of cheeses $\mathrm{F}$ and $\mathrm{G}$ were significantly $(P \leq 0.05)$ higher at 5360 and $5467 \mathrm{mg} \cdot \mathrm{kg}^{-1}$, respectively. It is interesting to note that, on increasing ripening temperature from that of treatment $\mathrm{A}\left(4^{\circ} \mathrm{C}\right)$ to that of treatment $\mathrm{G}\left(12{ }^{\circ} \mathrm{C}\right)$, the greatest difference in FFA levels at $60 \mathrm{~d}$ of ripening was for the short-chain FFA $\left(\Sigma\left(\mathrm{C}_{4: 0}-\mathrm{C}_{8: 0}\right)\right)$. This is an important observation, as shortchain FFA have low flavour thresholds [3] and have the propensity to contribute directly to Cheddar cheese flavour or can act as precursors for important flavour compounds (e.g., methyl ketones) once liberated $[20,38]$.

Increasing ripening temperature from 4 to $8{ }^{\circ} \mathrm{C}$ had little impact on FFA levels, while, an increase in ripening temperature of the same magnitude, from 8 to $12{ }^{\circ} \mathrm{C}$, resulted in a much faster rate of accumulation of FFA in the cheeses during ripening. This trend was evident at all stages of ripening up to $270 \mathrm{~d}$. At $270 \mathrm{~d}$, the levels of total FFA in cheeses A, B, C and D were $5608,6272,5622$ and $5918 \mathrm{mg} \cdot \mathrm{kg}^{-1}$, respectively, indicating an increase in total FFA levels of only $\sim 6 \%$ for a $4{ }^{\circ} \mathrm{C}$ increase in ripening temperature from 4 to $8^{\circ} \mathrm{C}$. The corresponding levels of FFA in cheeses $\mathrm{E}$, $\mathrm{F}$ and $\mathrm{G}$ at $270 \mathrm{~d}$ were 7015,7949 and $11926 \mathrm{mg} \cdot \mathrm{kg}^{-1}$, respectively. Thus, a $4{ }^{\circ} \mathrm{C}$ increase in ripening temperature from 8 to $12{ }^{\circ} \mathrm{C}$ resulted in a $\sim 100 \%$ increase in total FFA levels. There were significant $(P \leq 0.05)$ differences in the concentrations of short- $\left(\Sigma\left(\mathrm{C}_{4: 0^{-}} \mathrm{C}_{8: 0}\right)\right)$, medium- $\left(\Sigma\left(\mathrm{C}_{10: 0^{-}}\right.\right.$ $\left.\left.\mathrm{C}_{14: 0}\right)\right)$ and long- $\left(\Sigma\left(\mathrm{C}_{16: 0}-\mathrm{C}_{18: 3}\right)\right)$ chain FFA between cheeses ripened under conditions of treatments A, B, C, D, E, F or G at 60, 120 and $270 \mathrm{~d}$ of ripening (Tab. II). Thus, the increase in total FFA levels on increas- ing ripening temperature from 8 to $12{ }^{\circ} \mathrm{C}$ was due to increases in the levels of FFA within each of the short- medium- and longchain FFA classes; however, the greatest relative increase was again observed for short-chain FFA. FFA are important in generating the flavour and aroma of many cheese varieties $[20,37,38,63]$ and have been reported to contribute to the flavour and aroma of Cheddar cheese [3, 17, 18, 50].

The levels of total $\left(\Sigma\left(\mathrm{C}_{4: 0}-\mathrm{C}_{18: 3}\right)\right)$ FFA in cheeses $\mathrm{E}$ and $\mathrm{F}$ were 4764 and $5284 \mathrm{mg} \cdot \mathrm{kg}^{-1}$, respectively, at $120 \mathrm{~d}$. At this stage in the ripening process, cheeses $\mathrm{E}$ and $\mathrm{F}$ had both been ripened for $60 \mathrm{~d}$ at $8{ }^{\circ} \mathrm{C}$ and $60 \mathrm{~d}$ at $12{ }^{\circ} \mathrm{C}$ - the only difference being the order of the ripening temperature treatment; cheese $\mathrm{E}$ was ripened initially at $8{ }^{\circ} \mathrm{C}$ for $60 \mathrm{~d}$ and then transferred to $12^{\circ} \mathrm{C}$, while cheese $\mathrm{F}$ was ripened initially at $12{ }^{\circ} \mathrm{C}$ for $60 \mathrm{~d}$ and then transferred to $8^{\circ} \mathrm{C}$. It is presumed that, on transfer, the time taken for temperature equilibration within the cheese blocks (5-6 kg) was negligible in comparison to the duration of the ripening period. Interestingly, for cheeses of the same age $(120 \mathrm{~d})$, the total FFA levels were higher in those cheeses ripened at a higher initial temperature (i.e., during first 1-60 d). The increased accumulation of FFA in cheese $F$ compared to cheese E, during the first $60 \mathrm{~d}$ of ripening remained evident up to $270 \mathrm{~d}$ (Tab. II). Thus, it appears that a high temperature during the first $60 \mathrm{~d}$ of ripening is most effective at accelerating lipolysis. This is an important finding as it enables lipolysis (and consequently flavour generation) to be accelerated by ripening Cheddar cheese at a relatively high temperature (up to $12{ }^{\circ} \mathrm{C}$ ) during the early stages and then reducing the temperature, which would help prevent any adverse physical effects on Cheddar cheese texture normally associated with high ripening temperatures $\left(\geq 12^{\circ} \mathrm{C}\right)[13,14,16]$.

It is unlikely that differences recorded in FFA levels as a result of employing different ripening temperature-time treatments were due to differences in activity of lipoprotein lipase, as this enzyme is largely inactivated by pasteurisation [6] and is reported to be inactive at the $\mathrm{pH}$ and salt content of cheese [28]. It is possible that differences in 
the number of NSLAB in the cheeses (Fig. 1) were responsible for the differences observed in FFA levels. McSweeney et al. [39] reported lower levels of FFA in Cheddar cheese made from recombined milk (formulated from microfiltered skim milk and pasteurised cream) than that made from raw milk. Microfiltration reduced the number of NSLAB in the raw milk from 191 to $<1 \mathrm{cfu} \cdot \mathrm{mL}^{-1}$, with cheese made from recombined milk having NSLAB numbers $\sim 2 \log$ cycles lower than those in cheese made from raw milk, throughout ripening. Shakeel-Ur-Rehman et al. [53] also found that increases in total FFA concentrations paralleled increases in the numbers of NSLAB in Cheddar cheeses made from raw milk, pasteurised milk or various blends thereof during ripening.

The results obtained for relative distribution of individual FFA in this study were identical to those of many other studies involving Cheddar cheese $[4,35,36,47$, 51]. The actual levels of individual FFA may be slightly higher than those reported for previous studies using similar ripening temperatures; however, this apparent discrepancy may be due to the higher moisture content of the cheeses used in this study or differences in the lipase/esterase activity of the starter cultures used.

\subsection{Descriptive sensory analysis}

The mean panel scores from descriptive analysis of the sensory properties of the cheeses at 120 and $270 \mathrm{~d}$ of ripening are given in Table III. One-way analysis of variance (ANOVA) of the mean panel score data showed that, of the 31 descriptive terms, significant $(P \leq 0.05)$ differences existed between the cheeses for 9 of the descriptors (9 flavour attributes) at $120 \mathrm{~d}$. At $270 \mathrm{~d}$ of ripening, significant $(P \leq 0.05)$ differences existed between the cheeses for 9 of the descriptors also (1 odour and 9 flavour attributes) (Tab. III). At $120 \mathrm{~d}$ of ripening, the mean panel scores for the odour attributes 'Pungent' and 'Sulphur' increased slightly, and those for the odour attribute 'Cardboard' decreased slightly with increasing ripening temperature". The flavour attributes 'Rancid', 'Sulphur', 'Creamy', 'Fruity', 'Cooked animal fat/suet', 'Acidic', 'Processed', 'Cheddary' and 'Sulphur' after-flavour significantly $(P \leq 0.05)$ discriminated between the flavour of the cheeses at $120 \mathrm{~d}$ of ripening. In general, the mean panel scores for the flavour attributes 'Rancid', 'Sulphur', 'Fruity', 'Acidic', 'Cheddary' and 'Sulphur' after-flavour increased, while the mean panel scores for the flavour attributes 'Creamy', 'Cooked animal fat/suet' and 'Processed' decreased with increasing ripening temperature at $120 \mathrm{~d}$ (Tab. III).

It is clear from the mean panel score data that by $270 \mathrm{~d}$ of ripening, the 7 cheeses were divided into 2 distinct groups based on their sensory characteristics, with one group comprising cheeses $\mathrm{A}, \mathrm{B}, \mathrm{C}$ and $\mathrm{D}$ and the second group comprising cheeses $\mathrm{E}, \mathrm{F}$ and $\mathrm{G}$. The attribute 'Sulphur' significantly $(P \leq 0.05)$ discriminated between the odour of the cheeses, while the attributes 'Pungent', 'Rancid', 'Onion', 'Buttery', 'Acidic', 'Processed', 'Cheddary' and 'Strength' significantly $(P \leq 0.05)$ discriminated between the flavour of the cheeses at $270 \mathrm{~d}$ of ripening. In general, the mean panel scores for the flavour attributes 'Pungent', 'Rancid', 'Onion', 'Acidic', 'Cheddary' and 'Strength' increased, while the mean panel scores for the flavour attributes 'Buttery' and 'Processed' decreased with increasing ripening temperature at $270 \mathrm{~d}$ (Tab. III). Changes in the sensory profiles of the cheeses during ripening may be illustrated by the fact that the odour attribute 'Sulphur' and the flavour attributes 'Pungent', 'Onion', 'Buttery' and 'Strength' significantly $(P \leq 0.05)$ discriminated between the sensory properties of the cheeses at $270 \mathrm{~d}$, while there were no significant $(P>0.05)$ differences between the cheeses in terms of these odour and flavour attributes at $120 \mathrm{~d}$.

The flavour attribute 'Salty', while deemed not significant $(P>0.05)$ at discriminating between the sensory properties of the cheeses at both 120 and $270 \mathrm{~d}$ of ripening, was scored highly (mean panel score of 39-46) in all cheeses. It is therefore an important "note" or component of the background flavour of each of the cheeses although it is not a flavour attribute that 
Table III. Mean panel scores for the 10 aroma and 21 flavour/after-flavour attributes from descriptive sensory analysis of Cheddar cheeses ripened under conditions of each of treatments A, $\mathrm{B}, \mathrm{C}, \mathrm{D}, \mathrm{E}, \mathrm{F}$ or G at 120 and $270 \mathrm{~d}$ (averaged from duplicate analysis of data from 2 trials). See Table I for explanation of treatment codes.

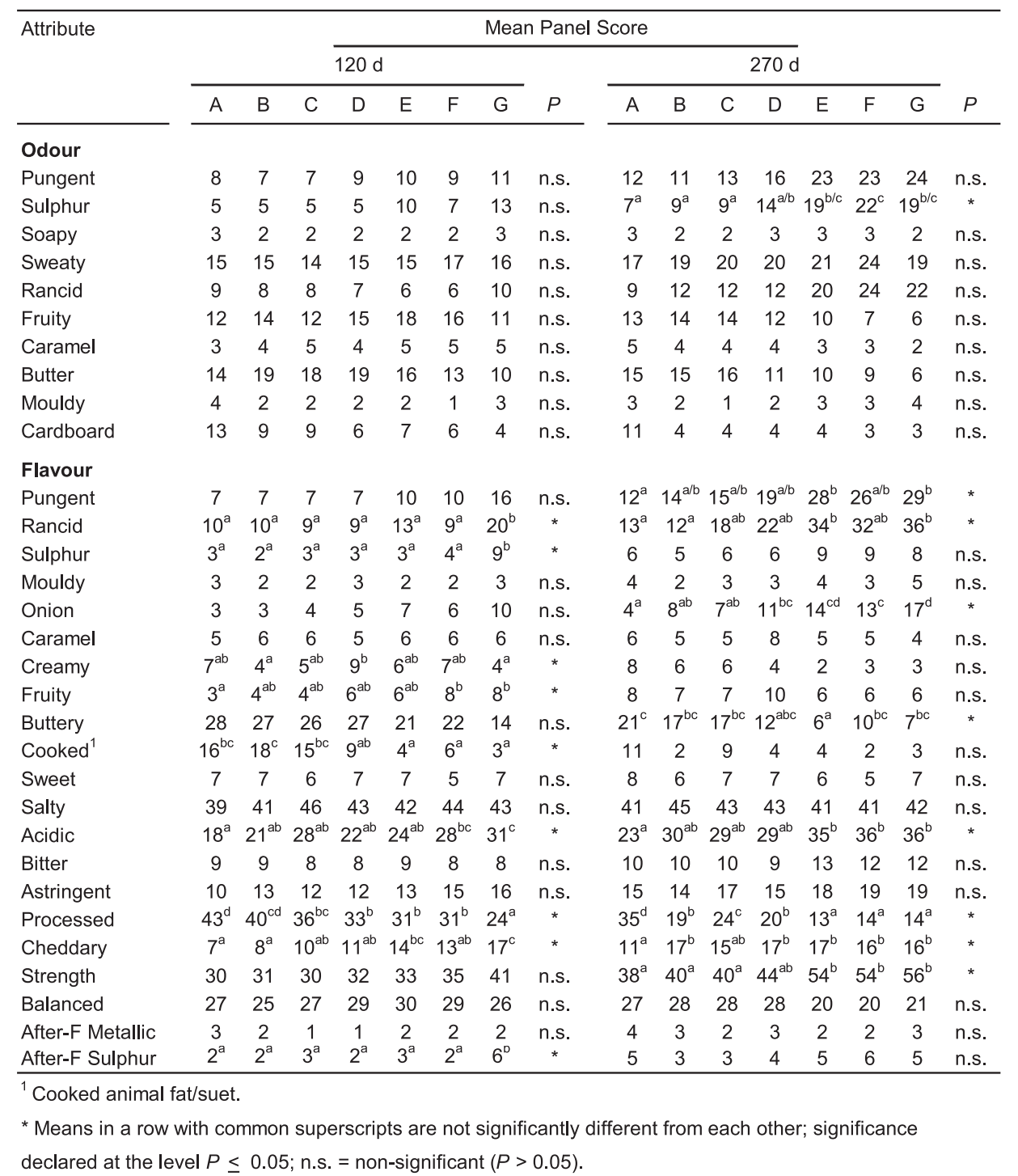

discriminated between the sensory properties of the cheeses. This is consistent with the relatively high salt content of the cheeses.
Various key aroma and flavour attributes have been identified and classified into a hierarchy based on relative importance using data obtained from quantitative 
descriptive analysis of sensory properties of 16 hard cheese varieties [40]. Among the 16 samples analysed by Muir et al. [40] were 3 Cheddar cheeses ranging in maturity from mild to mature and vintage. The results illustrated that the most important attributes for describing the sensory properties of hard cheeses include odour attributes 'Rancid' and 'Fruity/sweet' and flavour attributes 'Creamy', 'Sweet', 'Acid' and 'Sulphur/eggy'. The findings of Muir et al. [40] agree well with this study, in which many of the above attributes significantly $(P \leq 0.05)$ discriminated between the sensory properties of the cheeses ripened using different temperature-time treatments.

In a study of the sensory properties of Cheddar cheese during ripening for up to 12 months [41], it was reported that while there were systematic changes in 'Cheddar' aroma, 'Cheddar' flavour, 'Acid' flavour and 'Mouth-coating' character, the most sensitive indicator of age was 'Cheddar' flavour. In this study the 'Cheddary' attribute was also found to discriminate significantly $(P \leq 0.05)$ between the flavour of the cheeses at both 120 and $270 \mathrm{~d}$ of ripening. At $120 \mathrm{~d}$ of ripening, the 'Cheddary' flavour score increased significantly $(P \leq 0.05)$ with increasing ripening temperature, with cheeses $\mathrm{A}$ and $\mathrm{G}$ having mean panel scores of 7 and 17, respectively. However, by $270 \mathrm{~d}$ of ripening, the relative differences between the cheeses were less; cheese A had a mean panel score of 11 while all other cheeses had scores ranging from 15 to 17 (Tab. III). While the mean panel score for the 'Cheddary' flavour attribute generally increased with ripening temperature and time, the score for cheese $G$ actually decreased slightly (but not significantly; $P>0.05$ ) between 120 and 270 d of ripening, which paralleled the change in mean panel score for the 'Balanced' flavour attribute. It appears that the intensity of 'Cheddary' flavour in Cheddar cheese is, in general, a good index of maturity (in agreement with Muir et al. [41]); however, caution should be exercised with its interpretation if the possibility for evolution of atypical Cheddar cheese flavour exists during ripening (see below). The 'Cheddary' flavour attribute may be considered as the overall mix or balance of flavours in the cheese in comparison to that of typical Cheddar cheese. Thus, while scores for this attribute generally increase with increasing ripening time and temperature, the development of atypical Cheddar cheese flavour would be expected to impact negatively on the score for the 'Cheddary' flavour attribute.

ANOVA of the entire mean panel score data set from descriptive analysis of the sensory properties of the cheeses illustrated that the odour attributes 'Soapy', 'Caramel' and 'Mouldy' and flavour attributes 'Mouldy', 'Caramel', 'Sweet', 'Salty', 'Bitter', 'Balanced' and 'Metallic' after-flavour did not significantly $(P>0.05)$ distinguish between the sensory characteristics of the cheeses, and were consequently not included in the subsequent principal component analysis (PCA) of the sensory data. PCA of the data matrix of the attributes that significantly $(P \leq 0.05)$ discriminated between the sensory properties of the cheeses was used to identify the odour and flavour attributes responsible for the similarities and differences between the sensory characters of the cheeses. One-way ANOVA revealed significant $(P \leq 0.05)$ differences between the cheeses on the first two principal components of the PCA analysis. PC1 and PC2 explained 69 and $10 \%$, respectively, of the variation between the sensory characteristics of the cheeses. A bi-plot of the sample scores and sensory attribute loadings for $\mathrm{PC} 1$ and PC2 is shown in Figure 2. Visual assessment of the bi-plot shows that PC1 explained the variation between the samples largely in terms of ripening time, i.e., most of the cheeses at $120 \mathrm{~d}$ are located on the negative side of the PC1 axis, while, at $270 \mathrm{~d}$, nearly all the cheeses are scored on the positive side of the PC1 axis. The two notable exceptions to this general trend were cheeses $A$ and $G$, which were scored on the negative and positive sides of the PC1 axis, respectively, at both 120 and $270 \mathrm{~d}$ of ripening. Except for cheese $\mathrm{G}$, all cheeses ripened for $120 \mathrm{~d}$ were described as having a 'Fruity', 'Buttery' and 'Cardboard' odour and a 'Creamy', 'Buttery', 'Cooked animal fat/suet' and 'Processed' flavour. Except for cheese A, all cheeses ripened for $270 \mathrm{~d}$ 


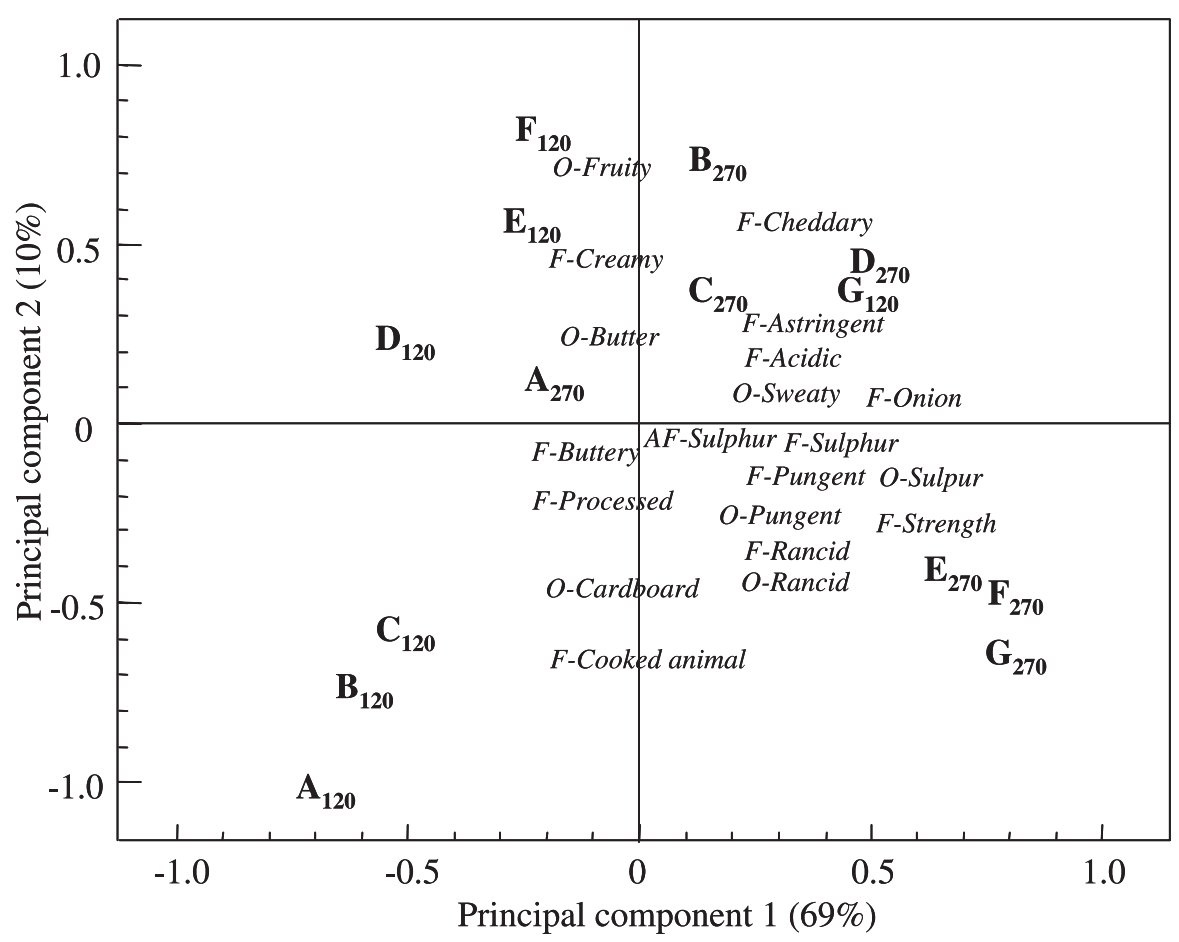

Figure 2. Bi-plot of principal component 1 and principal component 2 showing the sample scores and sensory attribute loadings from principal component analysis of descriptive sensory analysis data for Cheddar cheeses ripened under conditions of each of treatments A, B, C, D, E, F or G at 120 and $270 \mathrm{~d}$. Sample treatment codes are indicated by bold capital letters, accompanied by subscripts indicating ripening time (d). Sensory attribute loadings indicated by italics and prefaced by $O-, F$ - or $A F$ - indicating odour, flavour or after-flavour sensory attributes, respectively (averaged from duplicate analysis of data from 2 trials). See Table I for explanation of treatment codes.

were described as having a more 'Pungent', 'Sulphur', 'Sweaty', 'Rancid' odour and 'Pungent', 'Sulphur', 'Rancid', 'Onion', 'Acidic', 'Astringent' and 'Cheddary' flavour than those ripened for $120 \mathrm{~d}$. This is in agreement with the changes observed in sensory properties of Cheddar cheese during maturation by Muir et al. [41]. Interestingly, cheese A was scored on the negative side of the PC1 axis irrespective of age, although the intensity of many of the odour and flavour attributes of this cheese did change somewhat with age (see Tab. III). The mean panel scores for all sensory attributes of this cheese increased between 120 and $270 \mathrm{~d}$ of ripening, except 'Soapy',
'Mouldy' and 'Cardboard' odour and 'Buttery', 'Cooked', 'Processed' and 'Balanced' flavour, which remained unchanged or decreased slightly during this time. The results show that the sensory characteristics of cheese $A$ at $270 \mathrm{~d}$ were most similar to those of cheeses D, E and F at $120 \mathrm{~d}$, while cheeses ripened at the highest temperature $\left(12{ }^{\circ} \mathrm{C}\right)$ for the longest time $(270 \mathrm{~d})$, i.e., treatment $\mathrm{G}$, developed sensory profiles typical of mature Cheddar cheese in as little as $120 \mathrm{~d}$. It is apparent from the bi-plot in Figure 2 that the sensory profile of typical mature Cheddar cheese in this study (e.g., cheese D at $270 \mathrm{~d}$ ) was characterised by having a balance of 'Fruity', 'Butter' and 
'Sweaty' odour and 'Creamy', 'Cheddary', 'Astringent', 'Acidic' and 'Onion' flavour. The direction of development of the sensory character of the cheeses during ripening may be obtained by drawing a line connecting the scores for any one cheese at 120 and $270 \mathrm{~d}$ on the bi-plot in Figure 2. The direction of sensory character development was similar for cheeses A, B and C. However, the direction of sensory character development for cheeses $\mathrm{E}, \mathrm{F}$ and $\mathrm{G}$ was substantially different to that of cheeses A, $\mathrm{B}, \mathrm{C}$ or even D. It is clear from the bi-plot that the sensory profiles of cheeses $\mathrm{E}, \mathrm{F}$ and $\mathrm{G}$ at $270 \mathrm{~d}$ were characterised by having a strong 'Pungent', 'Rancid' and 'Sulphur' odour and 'Sulphur', 'Pungent', 'Strength' and 'Rancid' flavour, with a 'Sulphur' afterflavour. The sensory profiles of cheeses E, $\mathrm{F}$ and $\mathrm{G}$ were less balanced at $270 \mathrm{~d}$ than at $120 \mathrm{~d}$ of ripening. It may be inferred from the results that the sensory profiles of cheeses $\mathrm{E}, \mathrm{F}$ and $\mathrm{G}$ were typical of mature Cheddar cheese at $120 \mathrm{~d}$, but by $270 \mathrm{~d}$ of ripening the sensory profiles of the cheeses had evolved to become somewhat atypical of good quality mature Cheddar cheese.

\section{CONCLUSIONS}

The results of this study show that acceleration of lipolysis in Cheddar cheese can be achieved by increasing ripening temperature in the range 4 to $12^{\circ} \mathrm{C}$. However, the relative increase in lipolysis with increasing temperature appeared to be much greater at temperatures in excess of $8^{\circ} \mathrm{C}$, than increasing temperature in the range 4 to $8{ }^{\circ} \mathrm{C}$. The increase in FFA levels with increasing temperature for short- $\left(\mathrm{C}_{4 \cdot 0^{-}}\right.$ $\mathrm{C}_{8 \cdot 0}$ ) chain FFAs was greater than that for either the medium- $\left(\mathrm{C}_{10: 0}-\mathrm{C}_{14: 0}\right)$ or long$\left(\mathrm{C}_{16: 0}-\mathrm{C}_{18: 3}\right)$ chain fatty acids. Modifications to the traditional Cheddar cheese ripening treatment allowed distinct manipulation of the sensory profiles of the cheeses. Ripening at a high temperature $\left(12{ }^{\circ} \mathrm{C}\right)$ resulted in development of flavour and aroma characteristics to an intensity normally associated with mature Cheddar cheese in as little as $120 \mathrm{~d}$. However, continued ripening for up to $270 \mathrm{~d}$ at this temperature (or even at a subsequently reduced temperature) resulted in a decrease in 'Cheddary' flavour intensity and development of flavour and aroma characteristics considered atypical of mature Cheddar cheese. Conversely, ripening of Cheddar cheese at low temperature $\left(4{ }^{\circ} \mathrm{C}\right)$ retarded the development of mature flavour and aroma, irrespective of the duration of ripening (even up to $270 \mathrm{~d}$ ). In conclusion, the temperature parameter of the traditional Cheddar cheese ripening treatment may be increased to promote accelerated lipolysis and flavour development in maturing Cheddar cheese; however, in doing so, ripening time needs to be carefully adjusted to prevent any deleterious changes in sensory characteristics.

Acknowledgements: This research was funded by the Food Institutional Research Measure, which is administered by the Irish Government under the National Development Plan 2000-2006.

\section{REFERENCES}

[1] Arbige M.V., Freund P.R., Silver S.C., Zelro J.T., Novel lipase for Cheddar cheese flavour development, Food Technol. 40 (1986) 91-98.

[2] Chich J.F., Marchesseau K., Gripon J.C., Intracellular esterase from Lactococcus lactis subsp. lactis NCDO 763: purification and characterisation, Int. Dairy J. 7 (1997) 169174.

[3] Collins Y.F., McSweeney P.L.H., Wilkinson M.G., Lipolysis and free fatty acid catabolism in cheese: a review of current knowledge, Int. Dairy J. 13 (2003) 841-866.

[4] Collins Y.F., McSweeney P.L.H., Wilkinson M.G., Evidence of a relationship between autolysis of starter bacteria and lipolysis in Cheddar cheese during ripening, J. Dairy Res. 70 (2003) 105-113.

[5] Deeth H.C., Fitz-Gerald C.H., Lipolysis in dairy products: A review, Aust. J. Dairy Technol. 3 (1976) 53-64.

[6] Deeth H.C., Fitz-Gerald C.H., Lipolytic enzymes and hydrolytic rancidity in milk and milk products, in: Fox P.F. (Ed.), Developments in Dairy Chemistry, Vol. 2, Chapman and Hall, London, UK, 1983, pp. 195-240.

[7] Deeth C.H., Fitz-Gerald C.H., Wood A.F., A convenient method for determining the extent of lipolysis in milk, Aust. J. Dairy Technol. 30 (1975) 109-111.

[8] De Jong C., Badings H.T., Determination of free fatty acids in milk and cheese. Procedures for extraction, clean up, and capillary gas 
chromatographic analysis, J. High Res. Chromatogr. 13 (1990) 94-98.

[9] Drake M.A., McIngvale S.C., Gerard P.D., Cadwallader K.R., Civille G.V., Development of a descriptive language for Cheddar cheese, J. Food Sci. 66 (2001) 1422-1427.

[10] Driessen F.M., Inactivation of lipases and proteinases (indigenous and bacterial), in: Heat-induced changes in milk, Bull. 238, Int. Dairy Fed., Brussels, Belgium 1989.

[11] El Soda M., Pandian S., Recent developments in accelerated cheese ripening, J. Dairy Sci. 74 (1991) 2317-2335.

[12] Fedrick I.A., Technology and economics of the accelerated ripening of Cheddar cheese, Aust. J. Dairy Technol. 42 (1987) 33-36.

[13] Fedrick I.A., Dulley J.R., The effect of elevated storage temperatures on the rheology of Cheddar cheese, N.Z. J. Dairy Sci. Technol. 19 (1984) 141-150.

[14] Fenelon M.A., Ryan M.P., Rea M.C., Guinee T.P., Ross R.P., Hill C., Harrington D., Elevated ripening temperature of reduced fat Cheddar made with or without lacticin 3147 producing starter culture, J. Dairy Sci. 82 (1999) 10-22.

[15] Foda F.A., Hammond E.G., Reinbold G.W., Hotchkiss D.K., Role of fat in the flavor of Cheddar cheese, J. Dairy Sci. 57 (1974) 1137-1142.

[16] Folkertsma B., Fox P.F., McSweeney P.L.H., Accelerated ripening of Cheddar cheese at elevated temperatures, Int. Dairy J. 6 (1996) 1117-1134.

[17] Forss D.A., Review of the progress of dairy science: Mechanisms of formation of aroma compounds in milk and milk products, J. Dairy Res. 46 (1979) 691-706.

[18] Forss D.A., Patton S., Flavor of Cheddar cheese, J. Dairy Sci. 49 (1966) 89-91.

[19] Fox P.F., Law J., Enzymology of cheese ripening, Food Biotechnol. 5 (1991) 239-262.

[20] Fox P.F., Law J., McSweeney P.L.H., Wallace J., Biochemistry of cheese ripening, in: Fox P.F. (Ed.), Cheese: Chemistry, Physics and Microbiology, Vol. 1, General Aspects, Chapman and Hall, London, UK, 1993, pp. 389-438.

[21] Gilles J., Lawrence R.C., The assessment of Cheddar cheese quality by compositional analysis, N.Z. J. Dairy Sci. Technol. 8 (1973) 148-151.

[22] Guinee T.P., Wilkinson M.G., Mulholland E.O., Fox P.F., Influence of ripening temperature, added commercial enzyme preparations and attenuated mutant $\left(\mathrm{Lac}^{-}\right)$ Lactococcus lactis starter on the proteolysis and maturation of Cheddar cheese, Ir. J. Food Sci. Technol. 15 (1991) 27-52.
[23] Hannon J.A., Wilkinson M.G., Delahunty C.M., Wallace J.M., Morrissey P.A., Beresford T.P., Application of descriptive sensory analysis and key chemical indices to assess the impact of elevated ripening temperatures on the acceleration of Cheddar cheese ripening, Int. Dairy J. 15 (2005) 263-273.

[24] Holland R., Coolbear T., Purification of tributyrin esterase from Lactococcus lactis subsp. cremoris E8, J. Dairy Res. 63 (1996) 131-140.

[25] Ikins W.G., Kwak H.S., Zink G.S., Jeon I.J., Comparison of methods for quantitation of free fatty acids in cheese, J. Food Sci. 53 (1988) 1915-1916.

[26] ISO, Sensory analysis - guidelines for the selection, training and monitoring of assessors, Standard 8586-1:1993, Int. Organ. Stand., Geneva, Switzerland 1993.

[27] Jana A.H., Upadhyay K.G., Homogenisation of milk for cheesemaking - A review, Aust. J. Dairy Technol. 47 (1992) 72-79.

[28] Khalid N.M., Marth E.M., Lactobacilli their enzymes and role in ripening and spoilage of cheese, a review, J. Dairy Sci. 73 (1990) 2669-2684.

[29] Kheadr E.E., Vuillemard J.C., El-Deeb S.A., Impact of liposome-encapsulated enzyme cocktails on Cheddar cheese ripening, Food Res. Int. 36 (2003) 241-252.

[30] Kimura A., Kumura H., Ishizuka S., Mikawa K., Shimazaki K., Saito Z., Liberation of free fatty acids from milk fat by lactic acid bacteria, Milchwissenschaft 58 (2003) 609-611.

[31] Law B.A., Controlled and accelerated cheese ripening: The research base for new technologies, Int. Dairy J. 11 (2001) 383-398.

[32] Law B.A., Wigmore A., Effect of commercial lipolytic enzymes on flavour development in Cheddar cheese, J. Soc. Dairy Technol. 38 (1985) 86-88.

[33] Law B.A., Hosking Z.D., Chapman H.R., The effect of some manufacturing conditions on the development of flavour in Cheddar cheese, J. Soc. Dairy Technol. 32 (1979) 87-90.

[34] MacFie H.J., Bratchell N., Greenhoff K., Vallis I.V., Designs to balance the effect of order of presentation and first order carryover effects in hall tests, J. Sens. Stud. 4 (1989) 129-148.

[35] Marsili R., Monitoring chemical changes in Cheddar cheese during aging by high performance liquid chromatography and gas chromatography techniques, J. Dairy Sci. 68 (1985) 3155-3161.

[36] McNeill G.P., Connolly J.F., A method for the quantification of individual free fatty acids in Cheese: Application to ripening of Cheddar-type cheeses, Ir. J. Food Sci. Technol. 13 (1989) 119-128. 
[37] McSweeney P.L.H., Biochemistry of cheese ripening, Int. J. Dairy Technol. 57 (2004) 127-144.

[38] McSweeney P.L.H., Sousa M.J., Biochemical pathways for the production of flavour compounds in cheese during ripening: A review, Lait 80 (2000) 293-324.

[39] McSweeney P.L.H., Fox P.F., Lucey J.A., Jordan K.N., Cogan T.M., Contribution of the indigenous microflora to the maturation of Cheddar cheese, Int. Dairy J. 3 (1993) 613-634.

[40] Muir D.D., Hunter E.A., Banks J.M., Horne D.S., Sensory properties of hard cheese: identification of key attributes, Int. Dairy J. 5 (1995) 157-177.

[41] Muir D.D., Hunter E.A., Banks J.M., Horne D.S., Sensory properties of Cheddar cheese: changes during maturation, Food Res. Int. 28 (1996) 561-568.

[42] Mulder H., Taste and flavour forming substances in cheese, Neth. Milk Dairy J. 6 (1952) 157-167.

[43] Murray J.M., Delahunty C.M., Selection of standards to reference terms in a Cheddartype cheese flavour language, J. Sens. Stud. 15 (2000) 179-199.

[44] O'Connell P.B., Studies on Lipolysis in Cheese During Ripening, MSc thesis, National University of Ireland, Cork, Ireland, 2002.

[45] O'Keeffe A., Mulholland E., Kiely N., O'Brien M.F., Phelan J.A., Effect of ripening temperature, active $\mathrm{SH}$ group development and added proteinases on the rate of maturation of Cheddar cheese, Ir. J. Food Sci. Technol. 3 (1979) 74.

[46] O’Mahony J.A., Sousa M.J., McSweeney P.L.H., Proteolysis in miniature Cheddartype cheeses made using blends of chymosin and Cynara cardunculus proteinases as coagulant, Int. J. Dairy Technol. 56 (2003) 52-58.

[47] O’Mahony J.A., Auty M.A.E., McSweeney P.L.H., The manufacture of miniature Cheddar-type cheeses from milks with different fat globule size distributions, J. Dairy Res. 72 (2005) 338-348

[48] Ohren J.A., Tuckey S.L., Relation of flavour development in Cheddar cheese to chemical changes in the fat of the cheese, J. Dairy Sci. 52 (1967) 598-607.

[49] Park S.J., Yoon Y.H., A study on the effects of $\mathrm{Lac}^{-}$mutants, protease and elevated ripening temperature on the maturation of Cheddar cheese, Korean J. Dairy Sci. 9 (1987) 41-49.

[50] Patton S., Volatile acids and the aroma of Cheddar cheese, J. Dairy Sci. 46 (1963) 856-858.
[51] Reddy K.A., Marth E.H., Lipolysis in Cheddar cheese made with sodium chloride, potassium chloride or mixtures of sodium and potassium chloride, Milchwissenschaft 48 (1993) 488-493.

[52] Rogosa M., Mitchell J.A., Wiseman R.F., A selective medium for the isolation and enumeration of oral and fecal lactobacilli, J. Bacteriol. 62 (1951) 132-133.

[53] Shakeel-Ur-Rehman, McSweeney P.L.H., Banks J.M., Brechany E.Y., Muir D.D., Fox P.F., Ripening of Cheddar cheese made from blends of raw and pasteurised milk, Int. Dairy J. 10 (2000) 33-44.

[54] Singh A., Srinivasan R.A., Dudani A.T., Studies on exocellular and endocellular lipases of some of the lipolytic bacteria, Milchwissenschaft 28 (1973) 164-166.

[55] Singh T.K., Drake M.A., Cadwallader K.R., Flavor of Cheddar cheese: a chemical and sensory perspective, Comp. Rev. Food Sci. Technol. 2 (2003) 139-162.

[56] Stadhouders J., Veringa H.A., Fat hydrolysis by lactic acid bacteria in cheese, Neth. Milk Dairy J. 27 (1973) 77-91.

[57] Trujillo A.J., Guamis B., Laenuna J., Lopez M.B., Proteolytic activities of some milk clotting enzymes on ovine casein, Food Chem. 71 (2000) 449-457.

[58] Upadhyay V.K., McSweeney P.L.H, Acceleration of cheese ripening, in: Smith G. (Ed.), Dairy Processing, Improving Quality, Woodhead Publishing, Cambridge, UK, 2003, pp. 421-447.

[59] Urbach G., Relations between cheese flavour and chemical composition, Int. Dairy J. 3 (1993) 389-422

[60] Wijesundera C., Drury L., Role of milk fat in production of Cheddar cheese flavour using a fat-substituted cheese model, Aust. J. Dairy Technol. 54 (1999) 28-35.

[61] Wijesundera C., Drury L., Muthukumarapan K., Gunasakeran S., Everett D., Elucidation of the effect of fat globule size and shape on Cheddar cheese flavour development using a fat-substituted cheese model, Aust. J. Dairy Technol. 55 (2000) 9-15.

[62] Wilkinson M.G., Acceleration of cheese ripening, in: Fox P.F. (Ed.), Cheese: Chemistry, Physics and Microbiology, Vol. 1, General Aspects, Chapman and Hall, London, UK, 1993, pp. 523-555.

[63] Woo A.H., Kollodge S., Lindsay R.C., Quantification of major free fatty acids in several cheese varieties, J. Dairy Sci. 67 (1984) 874878 . 